\title{
Simulasi Pengontrol On/Off pada Sistem Kendali Umpan Balik dengan Model Fisis Elektronik
}

\author{
Darmawan Hidayat ${ }^{1, *}$, Meutia Rahmatika ${ }^{2}$, Nendi Suhendi Syafei ${ }^{3}$, Bernard Y. Tumbelaka \\ ${ }^{1,3,4}$ Departemen Teknik Elektro, FMIPA, Universitas Padjadjaran \\ Jl. Raya Bandung-Sumedang km. 21, Jatinangor, telp/fax: (022)7796014 \\ ${ }^{2}$ Departemen Fisika, FMIPA, Universitas Padjadjaran \\ Jl. Raya Bandung-Sumedang km. 21, Jatinangor, telp/fax: (022)7796014 \\ *Corresponding author: darmawan.hidayat@unpad.ac.id ${ }^{1}$, meutia_rahmatika@yahoo.com², \\ n.suhendi@unpad.ac.id ${ }^{3}$, btumbelaka@ymail.com ${ }^{4}$
}

\begin{abstract}
Abstrak - Pengontrol on/off merupakan salah satu jenis aksi pengontrolan yang banyak digunakan pada pengontrol otomatis karena sederhana dan relatif murah. Terdapat dua parameter respon sistem kendali yang harus dipertimbangkan pada aplikasi pengontrol on/off. Pertama adalah frekuensi osilasi respon yang menentukan osilasi aktuator dan memengaruhi umur ketahanan komponen aktuator. Kedua adalah amplitudo (deviasi) osilasi respon yang menentukan akurasi dan efisiensi energi pengontrolan. Makalah ini membahas kajian pengaruh parameter waktu tunda histeresis, T dan penguatan, M pengontrol on/off tersebut terhadap respon kendali umpan balik. Kajian dilakukan melalui simulasi MATLAB. Hasil simulasi dibandingkan dengan implementasi menjadi sistem fisis yang dibangun dengan suatu mikrokontroler digital, aktuator saklar elektronik, dan rangkaian elektronik proses dan komponen umpan balik dari komponen pasif resistor dan kapasitor $(R C)$. Hasil simulasi menunjukkan bahwa semakin besar nilai $T$ maka waktu yang dibutuhkan oleh sistem untuk mencapai keadaan mantap semakin lama, frekuensi osilasi keluaran semakin kecil, amplitudo osilasi respon semakin besar pula. Semakin besar nilai parameter M, maka waktu yang dibutuhkan oleh sistem untuk mencapai keadaan mantap semakin cepat, amplitudo respon semakin besar dan frekuensi osilasi semakin kecil. Berdasarkan pengujian, dapat disimpulkan bahwa respon pengontrolan umpan balik dengan menggunakan pengontrol on/off dapat diatur sesuai kriteria pengontrolan dengan mengatur parameter delay histeresis dan penguatan pengontrol on/off.
\end{abstract}

Kata Kunci: pengontrol on/off, waktu tunda histeresis, penguatan histeresis, model fisis elektronik, respon

\section{Pendahuluan}

Kontrol otomatik memegang peranan penting dalam perkembangan ilmu dan teknologi, serta aplikasi perangkat kebutuhan kehidupan manusia. Sebagai contohnya, kontrol otomatik sangat diperlukan pada pesawat ruang angkasa, peluru kendali, sistem pengemudian pesawat, dan sebagainya. Selain itu kontrol automatik telah menjadi bagian yang penting dan terpadu dari proses-proses dalam pabrik dan industri modern. Contohnya, dalam operasi-operasi untuk mengontrol tekanan, temperatur, kelembaban, viskositas dan lain-lain [1]. Beberapa pengontrol yang populer digunakan dalam kontrol otomatik adalah pengontrol PID dan pengontrol on/off atau two-position controller [2]. Pengontrol PID banyak ditanamkan pada pengontrol-pengontrol komersial karena memiliki tiga parameter pengontrolan proporsional, integral dan derivatif untuk mengatur respon sesuai kriteria yang ditentukan sehingga pengontrol PID memilki fleksibilitas tinggi. Pengaruh parameter PID terhadap respon sistem kendali umpan balik telah ditunjukkan melalui simulasi dan eksperimen $[3,4]$.

Pengontrol on-off merupakan pengontrol paling sederhana dan tangguh (robust) namun akurasi menjadi batasan ketika memerlukan pengontrolan akurasi tinggi karena variabel kendali (controlled variable) sistem selalu mengandung osilasi [1,5]. Pengontrol on-off banyak

TELKA, Vol.4, No.1, Mei 2018, pp. 43 53

ISSN (e): 2540-9123

ISSN (p): 2502-1982 
diterapkan pada sistem pengontrolan besaran fisis temperatur sistem pemanas, reaktor fermentasi, ruang klimatik, sistem pemanas ruangan, inkubator untuk bayi, sistem tinggi muka cairan [5, 69]. Di rumah tangga pengontrol on-off juga banyak digunakan seperti pada sistem penampung air, setrika listrik, oven listrik dan pemanas air [6].

Restrepo et al., (2002) melaporkan pengontrol on-off yang diberi waktu-tunda dapat memperbaiki performansi sistem kendali. Terdapat dua aspek penting yang harus dipertimbangkan pada pengontrol on-off. Pertama adalah frekuensi osilasi respon yang berpengaruh pada umur ketahanan komponen aktuator. Kedua adalah amplitudo osilasi respon yang memengaruhi akurasi pengendalian dan besar rugi-rugi energi pada respon sistem kendali keseluruhan. Beberapa strategi digunakan untuk memperbaiki performansi pengontrol on/off, seperti memadukan pengontrol on/off dengan pengontrol fuzzy [10-12], dan pengontrol model predictive [13]. Oleh karena itu, diperlukan suatu strategi untuk mengatur parameter frekuensi dan amplitudo osilasi respon.

Makalah ini memaparkan simulasi Matlab dan eksperimen implementasi sistem fisis pengaruh parameter waktu-tunda dan penguatan histeresis aksi pengontrol on/off terhadap respon suatu sistem kendali umpan balik untuk mengatur frekuensi dan amplitudo osilasi respon. Pengaruh parameter waktu-tunda dan penguatan histeresis terhadap frekuensi dan amplitudo osilasi respon diteliti berdasarkan analisis transien dan keadaan-mantap sistem kendali. Hasil simulasi dibandingkan dengan eksperimen implementasi pengontrol on/off pada sistem kendali umpan balik yang diwujudkan dalam suatu rangkaian mikrokontroler, saklar elektronik dan model fisis rangkaian elektronik.

\section{Metode}

Pemodelan melalui model fisis rangkaian elektronik juga dilakukan pemodelan melalui simulasi Matlab dengan menggunakan Simulink. Gambar 1.a menunjukkan diagram blok simulasi sistem pengontrol on/off pada sistem kendali umpan balik. Bagian utama sistem adalah (i) pengontrol on/off yang dibangun dari blok detektor kesalahan, delay transport, dan relay sebagai aktuator on/off; (ii) blok proses (plant), $G(s)$; dan (iii) komponen umpan balik, $H(s)$. Parameter waktu-tunda histeresis diatur melalui parameter blok delay transport, sedangkan penguatan histeresis diatur melalui parameter blok relay.

Misalkan sinyal keluaran kontroler adalah $U(s)$ dan sinyal kesalahan penggerak adalah $E(s)$. Pada kontrol dua posisi, sinyal $U(s)$ akan tetap pada harga maksimum atau minimum, bergantung pada tanda sinyal kesalahan penggerak, ' 1 ' atau ' 0 ', sedemikian rupa sehingga persamaan model aktuator yang digunakan adalah seperti Persamaan 1 :

$$
U(s)=\left\{\begin{array}{r}
M, \text { dan } E(s)=1, \text { untuk } C(s)<R(s) \\
0, \text { dan } E(s)=0, \text { untuk } C(s)>R(s)
\end{array}\right.
$$

Model fisis $G(s)$ dan $H(s)$ dibuat dalam orde-1 mengikuti Persamaan 2 dengan pilihan tiga model fisis $G(s)$ dan dua model $H(s)$ yang digunakan untuk simulasi, yaitu:

$$
\mathrm{G}(\mathrm{s})=\frac{1}{\tau s+1}
$$

dengan $\tau=R . C$ adalah konstanta waktu.

$$
\begin{aligned}
& G(s)_{I}=\frac{1}{\tau_{1} s+1}=\frac{1}{s+1} ; G(s)_{2}=\frac{1}{\tau_{2} s+1}=\frac{1}{22 s+1} ; G(s)_{3}=\frac{1}{\tau_{3} s+1}=\frac{1}{60 s+1} ; \text { dan } \\
& H(s)=1 ; \operatorname{dan} H(s)=\frac{1}{\tau 1 s+1}=\frac{1}{2,2 s+1}
\end{aligned}
$$


Masing-masing perbedaan konstanta waktu model $G(s)$ dan $H(s)$ mewakili sistem orde-1 dengan waktu settling cepat, sedang dan lambat.

Hasil simulasi dibandingkan dengan model fisis eksperimen implementasi model fisis sistem untuk verifikasi. Gambar 1.b memperlihatkan implementasi pengontrol on/off menjadi model fisis elektronik. Pengontrol on/off diwujudkan dengan menggunakan mikrokontroler MCS-51 karena pertimbangan kesederhanaan dalam arsitektur prosesor dan pemrogramannya. Pengontrol on/off dilengkapi dengan tombol entri setting point $(S P)$ dan peraga LCD untuk menampilkan nilai SP dan controlled variable $(C V)$. Model fisis $G(s)$ dan $H(s)$ diwujudkan dengan rangkaian orde-1 operational amplifier (opamp) seperti Gambar 1.c. Penguatan yang digunakan pada $G(s)$ adalah satu, yang diwujudkan dari opamp sebagai penyangga. Pada kenyataannya $G(s)$ dapat mewakili model fisis dari suatu sistem pemanas, sistem tangki air, dan sejenisnya. Blok $H(s)$ dapat mewakili model dari sensor yang meraba besaran respon $C V$. Elemen umpan balik yang digunakan sesuai dengan besaran fisis keluaran $C V$, sebagai contoh: jika $G(s)$ adalah sistem pemanas yang keluarannya adalah temperatur, maka $H(s)$ merupakan sensor temperatur, yang dapat berupa NTC, PTC, RTD, Termokopel dan sebagainya; jika $G(s)$ adalah sistem tangki air yang keluarannya adalah tinggi air, maka $H(s)$ merupakan sensor ketinggian, dapat berupa sensor potensiometrik.

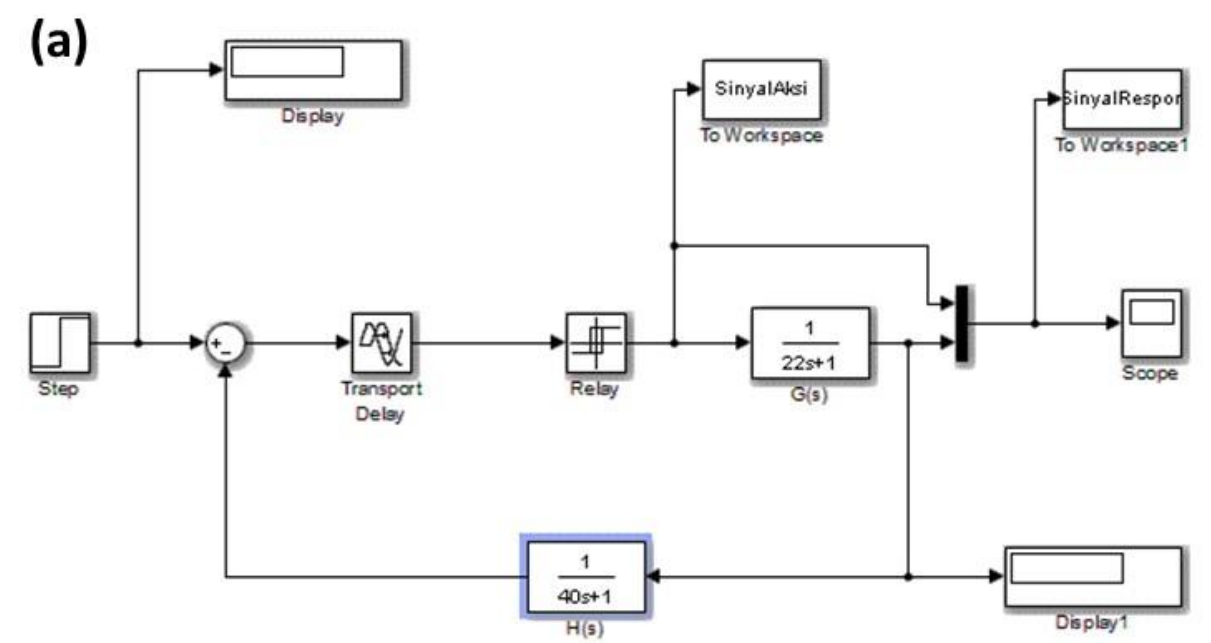

(b)

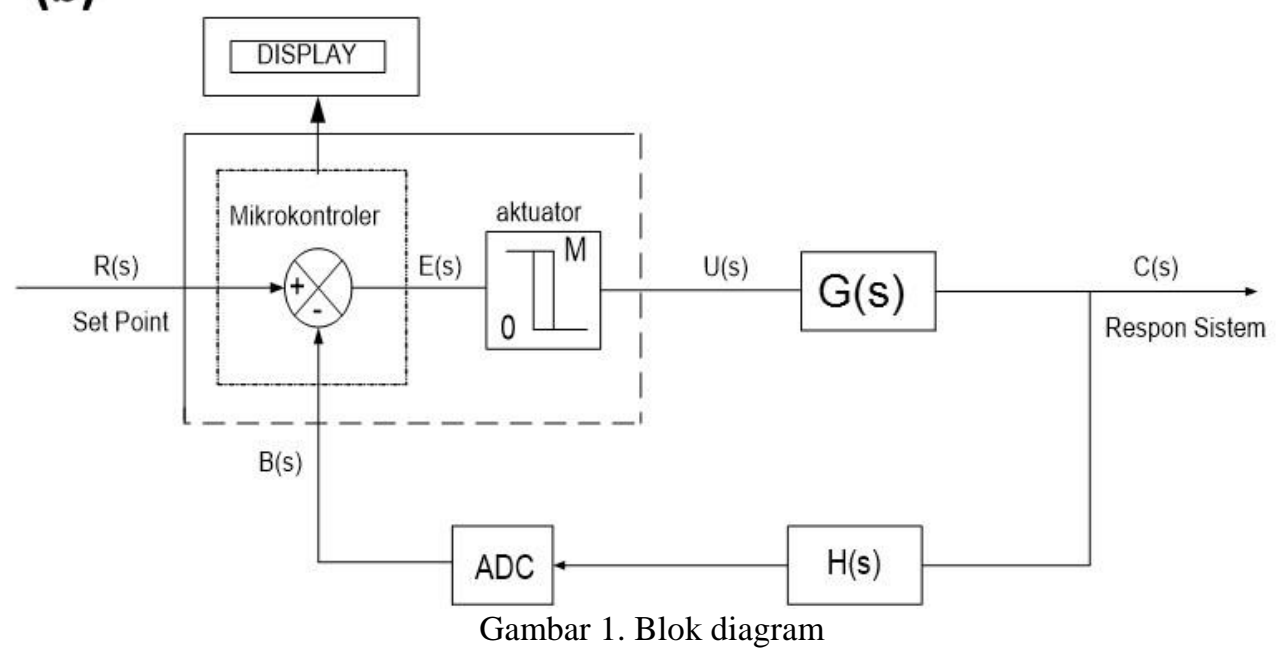

Seluruh sistem $\mathrm{G}(\mathrm{s})$ dan $\mathrm{H}(\mathrm{s})$ diperlihatkan pada Gambar 2. Untuk fungsi alih $G(s)$ yang pertama digunakan $\tau$ sebesar $1 \mathrm{~s}(R 10 \mathrm{k} \Omega, C 100 \mu \mathrm{F})($ Gambar 2.a), fungsi alih $G(s)$ yang kedua digunakan $\tau$ adalah $22 \mathrm{~s}(R 22 \mathrm{k} \Omega, \mathrm{C} 1006 \mathrm{uF})$ (Gambar 2.b), fungsi alih $G(s)$ yang ketiga digunakan $\tau$ sebesar $60 \mathrm{~s}(R 59.9 \mathrm{k} \Omega, C 1006 \mathrm{uF})$ (Gambar 2.c). 


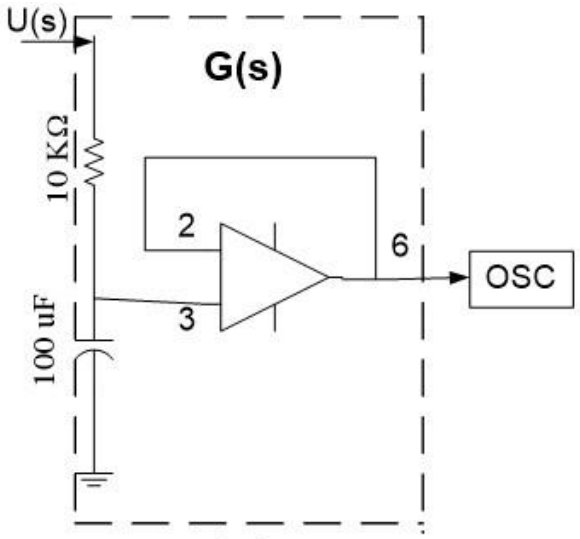

(a)

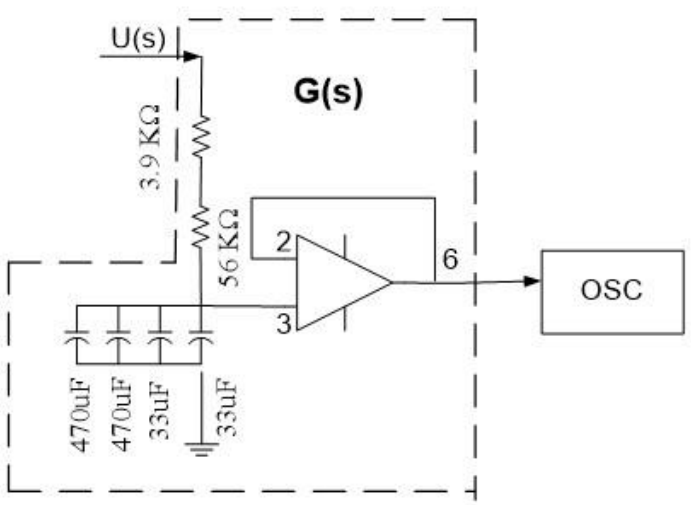

(c)

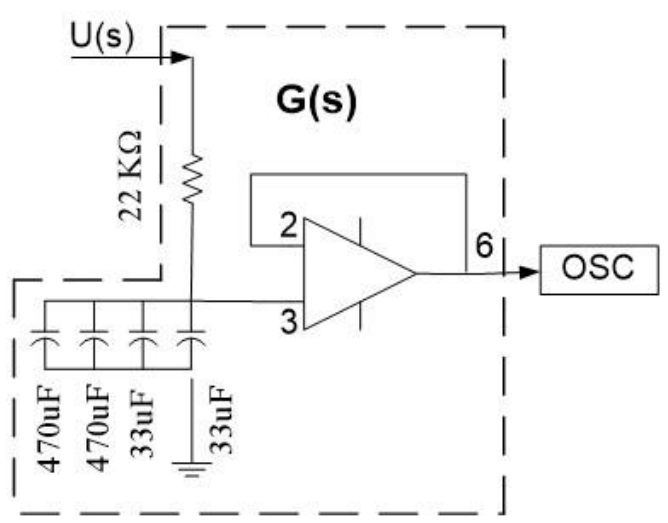

(b)

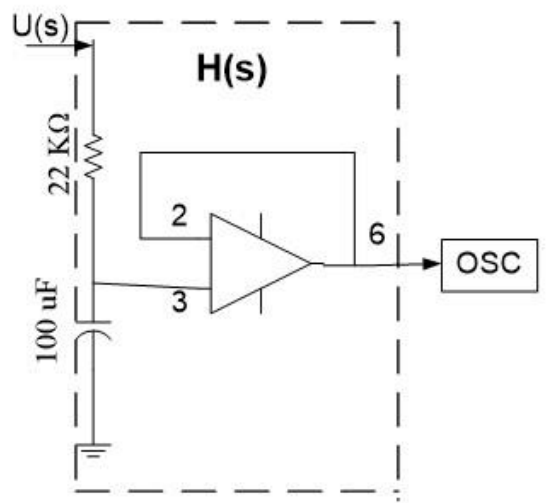

(d)

Gambar 2. Plant dengan tiga variasi fungsi alih (a) $G(s)=\frac{1}{s+1}$, (b) $G(s)=\frac{1}{22 s+1}$ dan (c) $G(s)=\frac{1}{60 s+1}$

Dalam memodelkan sistem dengan $H(s)$ yang dibuat dalam orde-1 yang diwujudkan dengan rangkaian elektronik $R C$ digunakan elemen umpanbalik $H(s)$ dengan dua macam variasi fungsi alih (Gambar 2.d). Untuk fungsi alih $H(s)$ yang pertama digunakan $\tau=2.2 \mathrm{~s}(R=22 \mathrm{k} \Omega ; C=100$ $\mathrm{uF})$, fungsi alih $G(s)$ yang kedua digunakan $\tau=40 \mathrm{~s}(R=39 \mathrm{k} \Omega ; C=1006 \mathrm{uF})$. Sedangkan fungsi alih proses $G(s)$ menggunakan $\tau=22 \mathrm{~s}(R=22 \mathrm{k} \Omega ; C=1006 \mathrm{uF})$.

Dengan teknik ini, seluruh besaran yang terlibat adalah besaran elektronik dalam bentuk tegangan, baik sinyal $C V$ dan sinyal aksi, bahkan sinyal umpan balik. Dengan begitu, secara praktis, seluruh sinyal dapat ditampilkan dan direkam oleh sebuah osiloskop guna keperluan pengamatan dan analisis.

\section{Hasil dan Pembahasan}

Pengaruh waktu tunda dan penguatan histeresis pengontrol on/off menentukan performansi terhadap respon sistem kendali umpan balik. Parameter respon meliputi frekuensi osilasi, amplitudo osilasi dan waktu settling. Hasil simulasi dibandingkan dengan hasil eksperimen implmentasi sistem menggunakan model fisis elektronik.

\subsection{Pengaruh waktu tunda histeresis pada respon}

Gambar 3 memperlihatkan variasi waktu tunda histeresis, $T$ sebesar 10, 30, 50 dan $180 \mathrm{~ms}$ dan nilai penguatan, $M$ konstan sebesar $5 \mathrm{~V}$, terhadap respon sistem dengan $G(s)=1 /(s+1)$ dan 
$H(s)=1$. Tampak bahwa terdapat osilasi, baik pada $C V$ maupun aktuator. Bentuk osilasi $C V$ adalah seperti gigi gergaji (warna merah) dan osilasi aktuator berada pada dua nilai biner nol dan $5 \mathrm{~V}$ (warna hijau). Nilai $S P$ berada pada rentang osilasi $C V$.

Untuk nilai $T$ sebesar $10 \mathrm{~ms}$ (Gambar 3.a), frekuensi osilasi $C V$, amplitudo osilasi dan waktu settling $C V$ masing-masing adalah $8,85 \mathrm{~Hz}, 0,105 \mathrm{~V}$ dan $0,258 \mathrm{~s}$. Seiring kenaikan nilai $T$ menjadi 30, 50 dan $180 \mathrm{~ms}$, frekuensi osilasi semakin menurun hingga 1,05 Hz. Begitu juga dengan osilasi aktuator, terlihat frekuensi aktuator semakin rendah dengan ditandai semakin renggangnya sinyal aktuator warna hijau. Hal ini baik untuk menjaga umur aktuator karena osilasi aktuator yang terlalu tinggi menurunkan umur operasi aktuator [14]. Selain itu, amplitudo osilasi $C V$ meningkat hingga $0,86 \mathrm{~V}$ dari $0,105 \mathrm{~V}$ yang ditunjukkan dari nilai puncak-ke-puncak $\left(V_{p p}\right)$ osilasi $C V$ semakin tinggi (warna merah). Peningkatan amplitudo $V_{p p}$ osilasi $C V$ meningkatkan rugi-rugi (losses) energi sistem pengontrolan. Seiring kenaikan nilai waktu tunda, waktu yang diperlukan untuk mencapai settling $\left(t_{\text {set }}\right)$ semakin lama hingga $0,41 \mathrm{~s}$ yang ditunjukkan dari semakin lebar waktu untuk mencapai waktu keadaan mantap. Tabel 1 merangkum seluruh nilai parameter respon dan aktuator untuk variasi dua fungsi transfer lainnya $G(s)$, yaitu: $1 /(22 s+1)$ dan $1 /(60 s+1)$, dan $H(s)=1$.
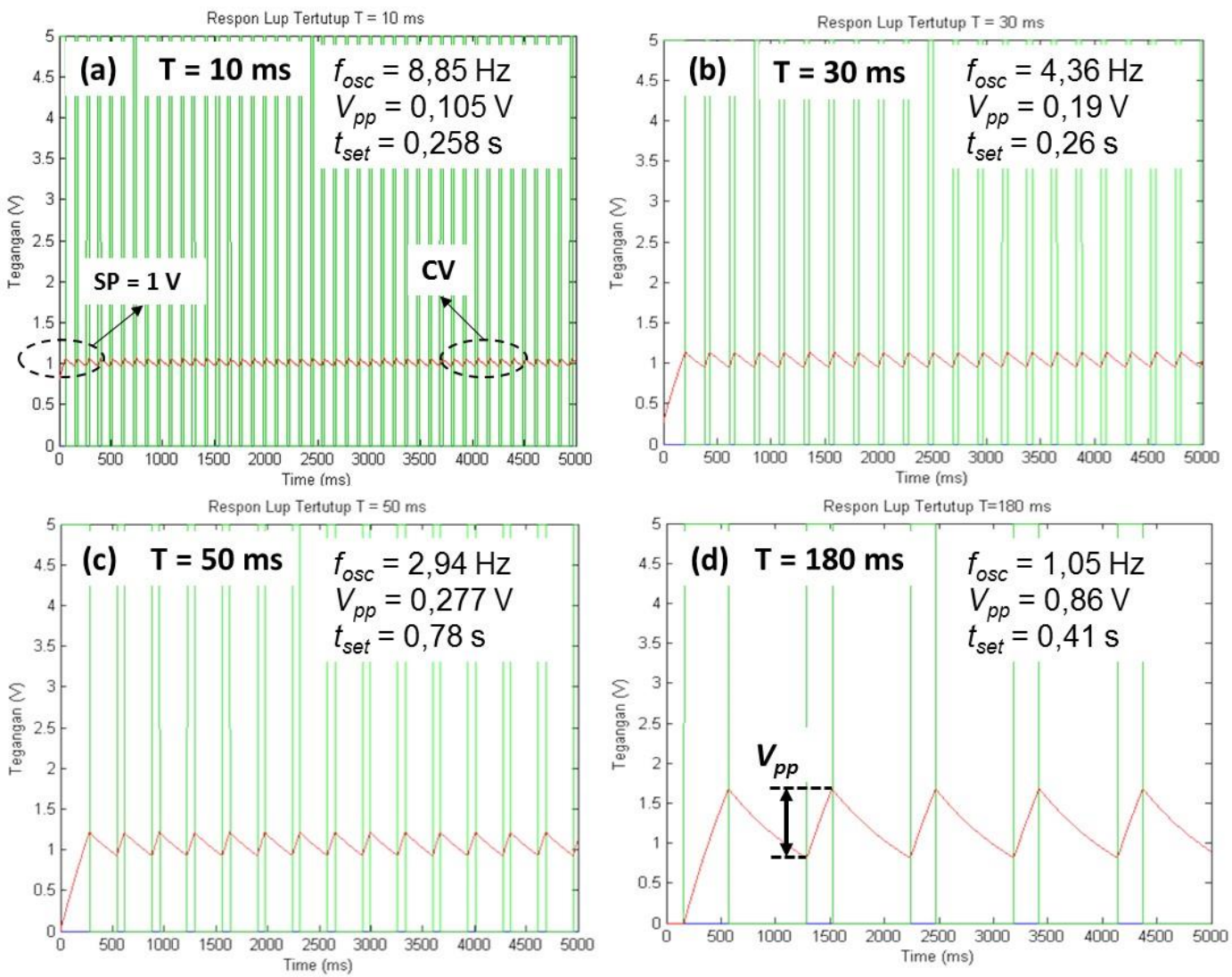

Gambar 3. Respon sistem kendali umpan balik pengontrol on/off dengan $G(s)=1 /(s+1)$ dan $H(s)=1$, nilai SP adalah $1 \mathrm{~V}$, penguatan histeresis, $M$ sebesar $5 \mathrm{~V}$, dan variasi waktu tunda, $T$ (a) $10 \mathrm{~ms}$, (b) $30 \mathrm{~ms}$, (c) $50 \mathrm{~ms}$ dan (d) $180 \mathrm{~ms}$

Dari respon sistem pengontrolan dan Tabel 1 terlihat bahwa semakin besar harga $T$ maka waktu yang dibutuhkan oleh sistem untuk mencapai keadaan mantap semakin lama. Hal ini diakibatkan karena adanya peristiwa pengisian dan pengosongan kapasitor pada $G(s)$ (plant atau proses). Dimana semakin besar harga $T$ yang berarti proses pengisian atau pengosongan berlangsung lebih lama. Sehingga harga keluaran jauh menyimpang dari kriteria yang diinginkan. Selain itu dengan semakin besarnya harga $T$ maka frekuensi osilasi keluarannya semakin kecil. Hal ini diakibatkan karena jika diberi delay $T$, aktuator relay memberikan sinyal on atau off pada $G(s)$ sehingga plant terus bekerja sehingga keluaran terus meningkat atau turun walaupun sudah 
mencapai nilai $S P$, yang mengurangi osilasi aktuator. Begitu juga dengan amplitudo osilasi $C V$ semakin besar pula yang berarti mengakibatkan energi yang terbuang semakin besar juga.

Tabel 1. Pengaruh waktu tunda histeresis terhadap respon

\begin{tabular}{|c|c|c|c|c|c|c|}
\hline \multirow{2}{*}{$G(s)$} & \multirow{2}{*}{$\mathbf{S P}(\mathrm{V})$} & \multirow{2}{*}{$\begin{array}{l}M \\
\text { (V) }\end{array}$} & \multirow{2}{*}{$T(\mathrm{~s})$} & \multicolumn{3}{|c|}{$C(s)$} \\
\hline & & & & $f_{\text {osc }}(\mathrm{Hz})$ & $V_{p p}$ (Volt) & $t_{\text {set }}(\mathbf{s})$ \\
\hline \multirow{4}{*}{$1 /(s+1)$} & 1 & 5 & 0,01 & 8,85 & 0,105 & 0,258 \\
\hline & 1 & 5 & 0,03 & 4,36 & 0,19 & 0,26 \\
\hline & 1 & 5 & 0,05 & 2,94 & 0,277 & 0,278 \\
\hline & 1 & 5 & 0,18 & 1,05 & 0,86 & 0,41 \\
\hline \multirow{4}{*}{$1 /(22 s+1)$} & 1 & 5 & 0,6 & 0,21 & 0,176 & 5,63 \\
\hline & 1 & 5 & 1 & 0,15 & 0,263 & 6,03 \\
\hline & 1 & 5 & 1,2 & 0,13 & 0,302 & 6,23 \\
\hline & 1 & 5 & 1,5 & 0,11 & 0,364 & 6,53 \\
\hline \multirow{4}{*}{$1 /(60 s+1)$} & 1 & 5 & 1,5 & 0,08 & 0,164 & 15,2 \\
\hline & 1 & 5 & 2 & 0,07 & 0,202 & 15,7 \\
\hline & 1 & 5 & 4 & 0,04 & 0,363 & 17,7 \\
\hline & 1 & 5 & 5 & 0,03 & 0,438 & 18,7 \\
\hline
\end{tabular}

\subsection{Pengaruh penguatan histeresis pada respon}

Gambar 4 memperlihatkan variasi penguatan histeresis, $M$ sebesar 2, 3, 4 dan $5 \mathrm{~V}$ dan nilai waktu tunda $T$ konstan $1 \mathrm{~s}$ terhadap respon sistem dengan $G(s)=1 /(s+1)$ dan $H(s)=1$. Tampak bahwa terdapat osilasi juga, baik pada $C V$ maupun aktuator seperti halnya pada Gambar 3. Bentuk osilasi $C V$ adalah seperti gigi gergaji (warna merah) dan osilasi aktuator berada pada dua nilai biner nol volt dan $M$ (warna hijau).

Untuk nilai $M$ sebesar $2 \mathrm{~V}$ (Gambar 4.a), frekuensi osilasi $C V$, amplitudo osilasi dan waktu settling $C V$ masing-masing adalah $5 \mathrm{~Hz}, 0,0985 \mathrm{~V}$ dan 0,686 s. Seiring kenaikan nilai $M$ menjadi 3, 4 dan $5 \mathrm{~V}$, frekuensi osilasi semakin menurun hingga 4,40 Hz. Begitu juga dengan osilasi aktuator, terlihat frekuensi aktuator semakin rendah dengan ditandai semakin renggangnya sinyal aktuator warna hijau. Namun begitu, amplitudo osilasi puncak-ke-puncak $\left(V_{p p}\right) C V$ meningkat hingga $0,190 \mathrm{~V}$ dari $0,0985 \mathrm{~V}$. Jelas bahwa peningkatan amplitudo $V_{p p}$ osilasi $C V$ meningkatkan rugi-rugi (losses) energi sistem pengontrolan.

Kecepatan respon semakin baik dengan peningkatan nilai $M$. Hal ini dapat dilihat dari nilai waktu settling, $t_{\text {set }}$ respon. Seiring kenaikan nilai penguatan histeresis, waktu yang diperlukan untuk mencapai settling $\left(t_{\text {set }}\right)$ semakin cepat hingga $0,260 \mathrm{~s}$ (Gambar 4.d) yang ditunjukkan dari semakin sempit waktu untuk mencapai waktu keadaan mantap. Tabel 2 merangkum seluruh nilai parameter respon dan aktuator untuk variasi dua fungsi transfer lainnya $G(s)$, yaitu: $1 /(22 s+1)$ dan $1 /(60 \mathrm{~s}+1)$, dan $\mathrm{H}(\mathrm{s})=1$. 

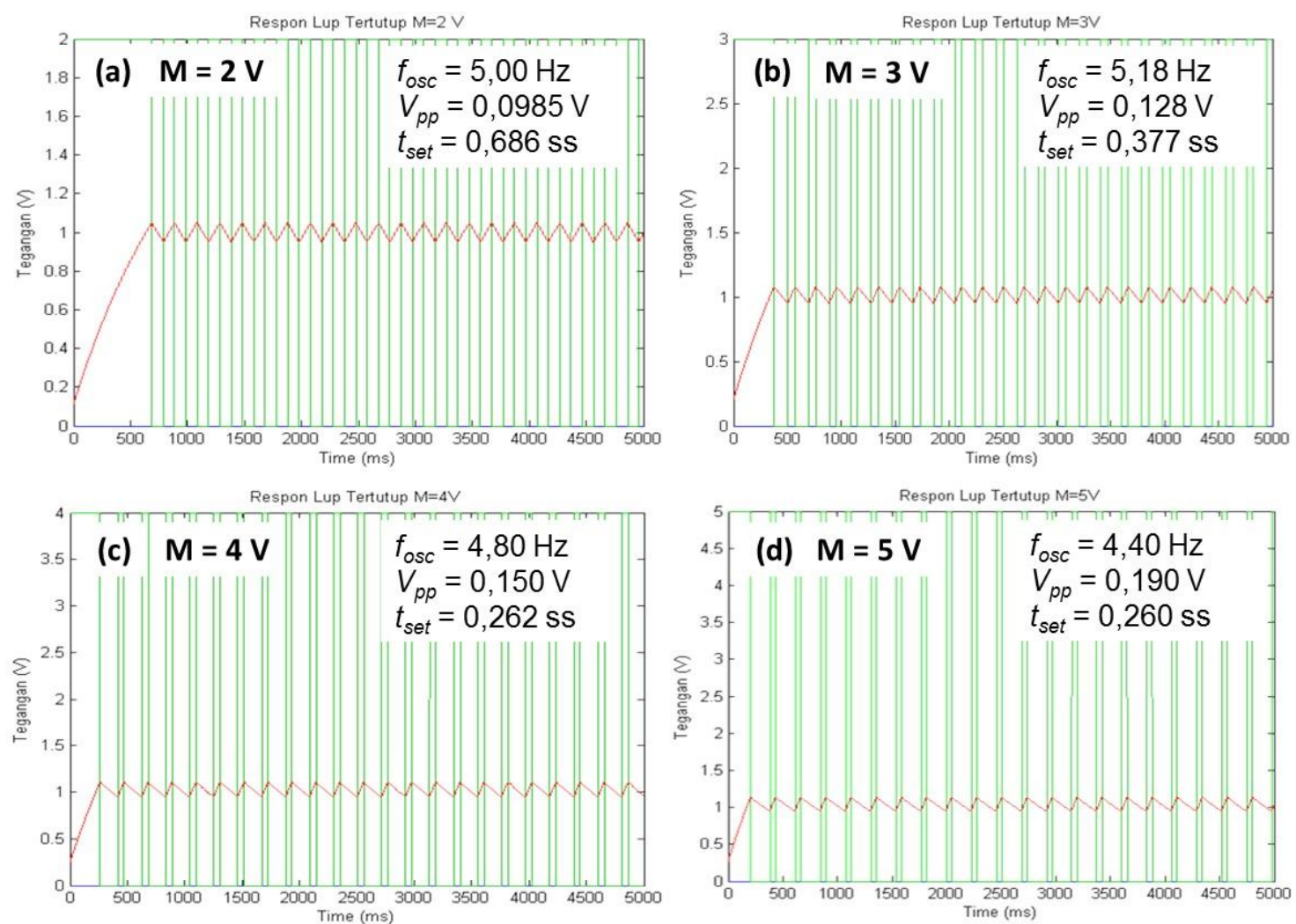

Gambar 4. Pengaruh penguatan histeresis, $M$ pada sistem umpan balik $G(s)=1 /(s+1)$ dan $H(s)=1$ dengan waktu tunda, $T$ sebesar $0,03 \mathrm{~s}$ dan variasi penguatan $M$ (a) $2 \mathrm{~V}$, (b) $3 \mathrm{~V}$, (c) $4 \mathrm{~V}$ dan (d) $5 \mathrm{~V}$

Tabel 2. Pengaruh penguatan M terhadap respon $G(s)$ variasi dan $H(s)=1$

\begin{tabular}{|c|c|c|c|c|c|c|}
\hline \multirow{2}{*}{$G(s)$} & \multirow{2}{*}{$\mathbf{S P}(\mathbf{V})$} & \multirow{2}{*}{$\begin{array}{l}M \\
(\mathbf{V})\end{array}$} & \multirow{2}{*}{$T$ (s) } & \multicolumn{3}{|c|}{$C(s)$} \\
\hline & & & & $f_{o s c}(\mathbf{H z})$ & $V_{p p}$ (Volt) & $t_{\text {set }}(\mathrm{s})$ \\
\hline \multirow{4}{*}{$1 /(s+1)$} & 1 & 2 & 0,03 & 5 & 0,098 & 0,686 \\
\hline & 1 & 3 & 0,03 & 5,18 & 0,128 & 0,377 \\
\hline & 1 & 4 & 0,03 & 4,8 & 0,15 & 0,262 \\
\hline & 1 & 5 & 0,03 & 4,4 & 0,19 & 0,26 \\
\hline \multirow{4}{*}{$1 /(22 s+1)$} & 1 & 2 & 0,5 & 0,27 & 0,082 & 16,2 \\
\hline & 1 & 3 & 0,5 & 0,28 & 0,102 & 9,61 \\
\hline & 1 & 4 & 0,5 & 0,27 & 0,132 & 6,97 \\
\hline & 1 & 5 & 0,5 & 0,24 & 0,152 & 5,54 \\
\hline \multirow{4}{*}{$1 /(60 s+1)$} & 1 & 2 & 1 & 0,12 & 0,076 & 43,8 \\
\hline & 1 & 3 & 1 & 0,12 & 0,086 & 25,9 \\
\hline & 1 & 4 & 1 & 0,12 & 0,106 & 18,7 \\
\hline & 1 & 5 & 1 & 0,11 & 0,121 & 14,7 \\
\hline
\end{tabular}

Tabel 2 respon sistem pengontrolan memperlihatkan bahwa semakin besar harga $M$ maka waktu yang dibutuhkan oleh sistem untuk mencapai keadaan mantap semakin cepat. Hal ini sesuai dengan teori pengisian kapasitor, dimana semakin besar daya $M$ yang diberikan, maka semakin sedikit waktu yang diperlukan untuk mengisi kapasitor hingga penuh. Namun begitu, jika harga $M$ semakin besar, sementara delay waktu $T$ pengontrolnya bernilai sama maka respon keluaran dengan $M$ yang lebih besar lebih dulu mencapai keadaan mantap sehingga keluarannya terus naik atau turun menuju nilai SP. Sehingga amplitudo (deviasi) keluaran semakin besar dan frekuensi osilasi keluaran semakin kecil. Selain itu dapat dilihat juga bahwa jika semakin besar nilai 
konstanta waktu $\tau$ sistem, maka semakin lama waktu yang diperlukan untuk mengisi kapasitor hingga penuh.

\subsection{Pengaruh waktu tunda histeresis}

Pada kenyataannya, karakter komponen umpan balik banyak juga mengikuti perilaku orde1 , orde-2 bahkan orde lebih tinggi. Untuk melihat respon sistem dengan komponen umpan balik adalah sistem dinamik, maka simulasi dilakukan dengan membuat komponen umpan balik $H(s)$ dalam orde-1. Untuk itu, fungsi transfer komponen sistem adalah $G(s)=1 /(22 \mathrm{~s}+1)$ dan $\mathrm{H}(\mathrm{s})=$ $1 /(2,2 \mathrm{~s}+1)$. Simulasi dilakukan dengan menentukan nilai penguatan histeresis, $M$ adalah $5 \mathrm{~V}$ dan variasi waktu tunda adalah $0,5,1,0,1,5$ dan $2 \mathrm{~s}$.

Hasil simulasi ditunjukkan pada Gambar 5. Seperti halnya $H(s)=1$, pengaruh waktu tunda histeresis terhadap tiga parameter respon sistem untuk komponen $\mathrm{H}(\mathrm{s})$ orde-1 menunjukkan kecenderungan yang sama. Gambar 5 menunjukkan bahwa semakin besar waktu tunda $T$, maka:

1. Waktu yang diperlukan oleh sistem untuk mencapai kondisi mantap, $t_{s e t}$ semakin lama.

2. Amplitudo osilasi $C V$ semakin besar.

3. Frekuensi osilasi $C V$ berkurang. Hal ini sangat diharapkan karena dengan berkurangnya kondisi 'on-off' maka dapat memperpanjang umur ketahanan komponen.
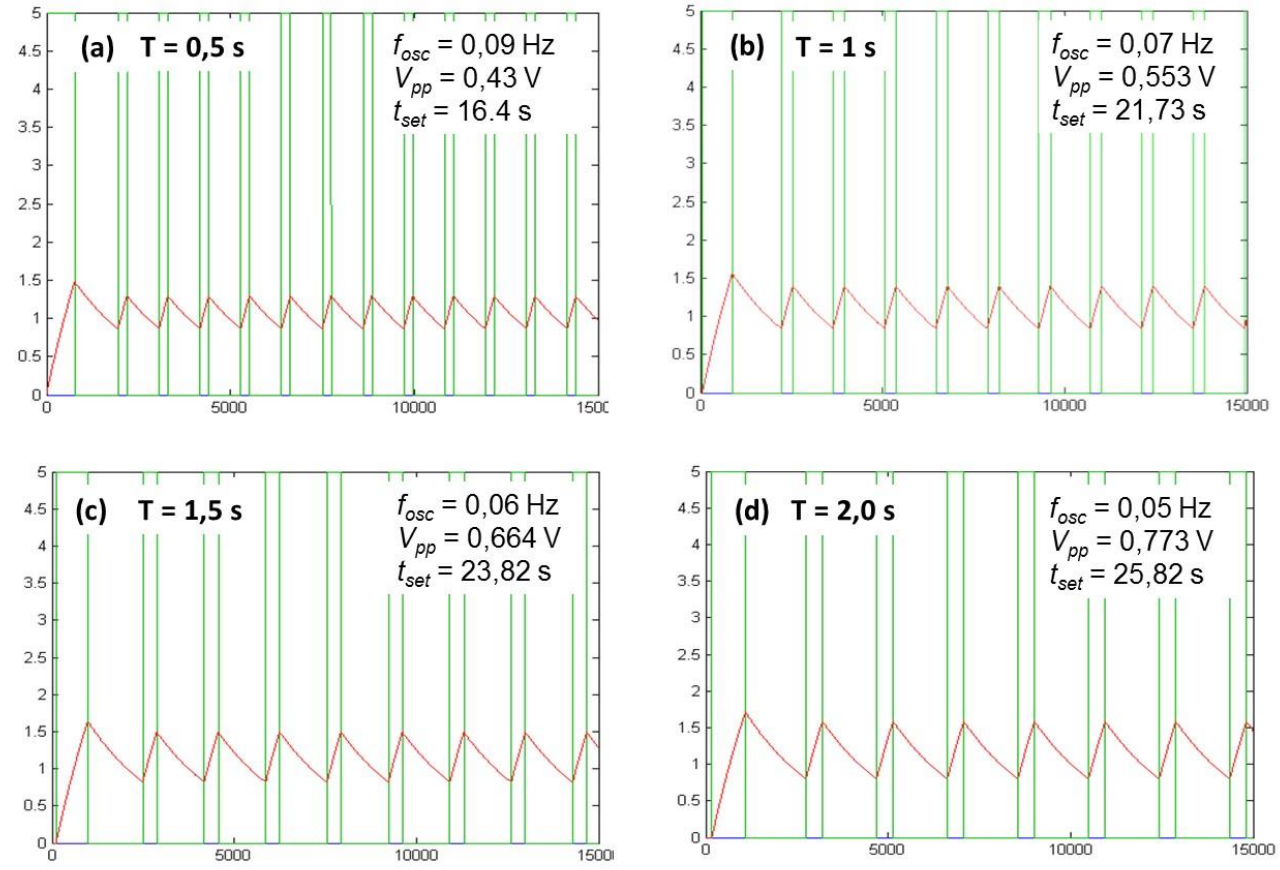

Gambar 5. Pengaruh waktu tunda histeresis $G(s)=1 /(22 s+1)$ dan $H(s)=1 /(2,2 s+1)$ dengan waktu tunda, $T$ sebesar (a) $0,5 \mathrm{~s}$, (b) $1 \mathrm{~s}$, (c) $1,5 \mathrm{~s}$ dan (d) $2 \mathrm{~s}$

\subsection{Implementasi sistem dengan model fisis elektronik}

Untuk verifikasi hasil simulasi, sistem kendali umpan balik diimplementasikan dalam wujud model fisis elektronik seperti diperlihatkan pada Gambar 1.b. Gambar 6 memperlihatkan pengaruh parameter waktu-tunda histeresis terhadap sinyal aksi $U(s)$ dan sinyal respon $C(s)$. Proses $G(s)$ adalah $1 /(\mathrm{s}+1)$ dan $H(s)$ sama dengan satu. Parameter penguatan histeresis, $M$ adalah $5 \mathrm{~V}$. Untuk waktu-tunda $10 \mathrm{~ms}$ (Gambar 6.a), sinyal respon $C(s)$ berada dekat dengan nilai-acuan $R(s)$, yang ditandakan dengan osilasi sinyal respon berada dekat nilai-acuan (nilai $V_{p p}$ sebesar 0,12 V). Hasil ini menandakan bahwa akurasi pengontrolan relatif baik. Namun, sinyal aksi $C(s)$ berosilasi dengan frekuensi relatif tinggi yang dapat mengakibatkan penurunan-ketahanan umur komponen aktuator. Dengan memperlambat waktu-tunda menjadi 30, 50 dan 180 ms (Gambar 
2.b, c dan d) frekuensi osilasi respon dan sinyal aksi (aktuator) menjadi semakin rendah dan waktu-settling semakin cepat. Namun, akurasi pengontrolan semakin turun, yang ditandai dengan meningkatnya amplitudo osilasi respon (nilai Vpp membesar) yang mengakibatkan rugi-rugi energi pengontrolan semakin tinggi. Hasil ini menunjukkan bahwa frekuensi osilasi dan amplitudo (akurasi) sinyal respon sistem kendali on-off dapat diatur (ditala) dengan variasi parameter waktu-tunda histeresis $[1,11,14]$.
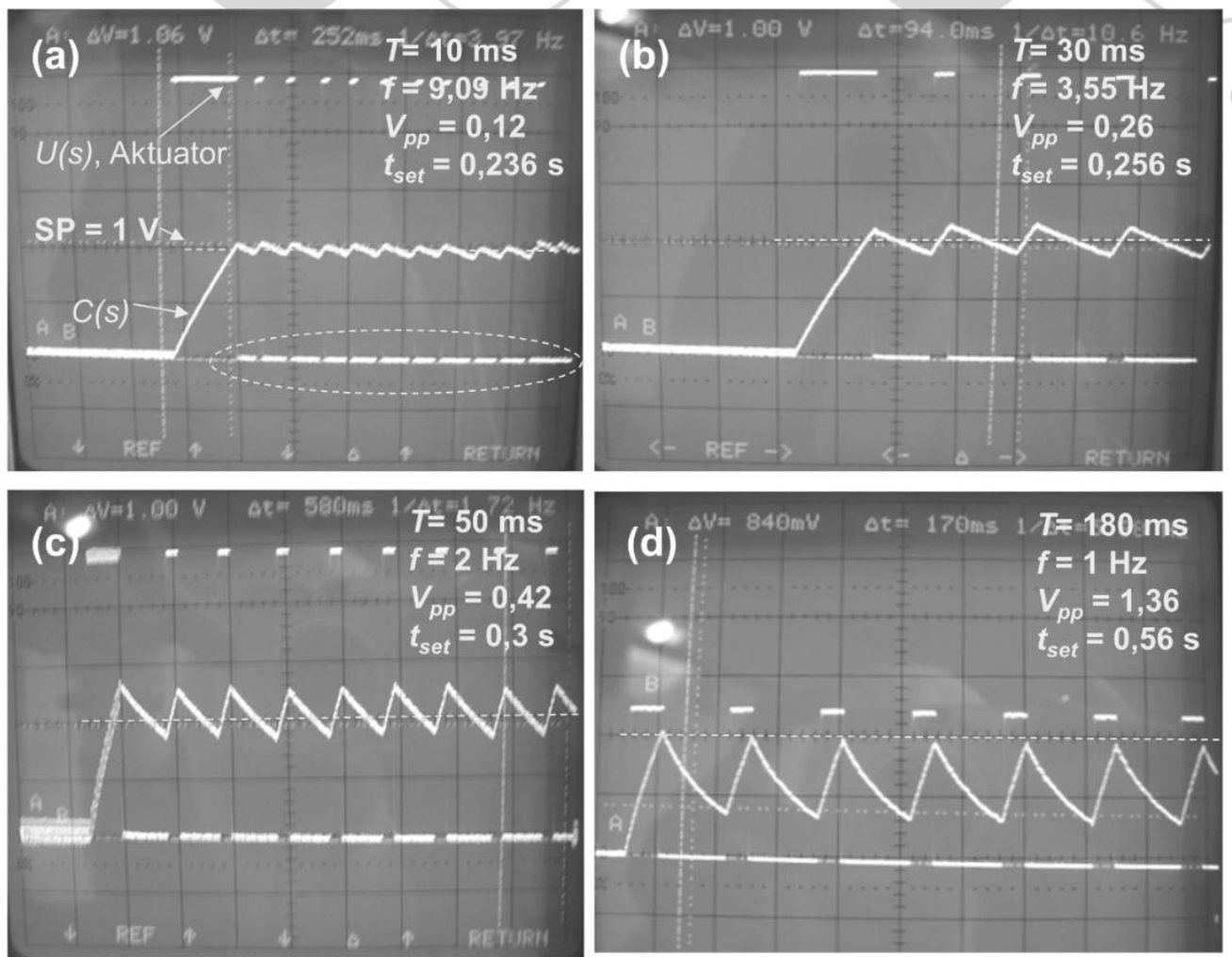

Gambar 6. Pengaruh parameter waktu-tunda histeresis terhadap frekuensi dan amplitudo osilasi respon untuk penguatan, $M$ sebesar $5 \mathrm{~V}$ dan waktu-tunda, $T$ (a) $10 \mathrm{~ms}$, (b) $30 \mathrm{~ms}$, (c) $50 \mathrm{~ms}$ dan (d) $180 \mathrm{~m}$

Gambar 7 memperlihatkan implementasi model fisis elektronik sistem yang disimulasikan pada Gambar 5 dengan $G(s)=1 /(22 \mathrm{~s}+1)$ dan $\mathrm{H}(\mathrm{s})=1 /(2,2 \mathrm{~s}+1)$, dengan penguatan, $M$ sebesar 5 $\mathrm{V}$ dan variasi waktu-tunda, $T$ (a) $0,5 \mathrm{~s}$, (b) $1 \mathrm{~s}$, (c) 1,5 s dan (d) $2 \mathrm{~s}$. Hasil eksperimen Gambar 7 sesuai dengan hasil simulasi Gambar 5 dan memperlihatkan bahwa dengan semakin besarnya parameter delay $\mathrm{T}$ yang diberikan, maka :

1. Waktu settling $t_{\text {set }}$ semakin lama.

2. Osilasi amplitudo $C V$ semakin besar.

3. Frekuensi osilasi $C V$ berkurang, yang berarti frekuensi osilasi aktuator mengecil. Hal ini sangat diharapkan karena dengan berkurangnya kondisi 'on-off' maka dapat memperpanjang umur ketahanan komponen. 

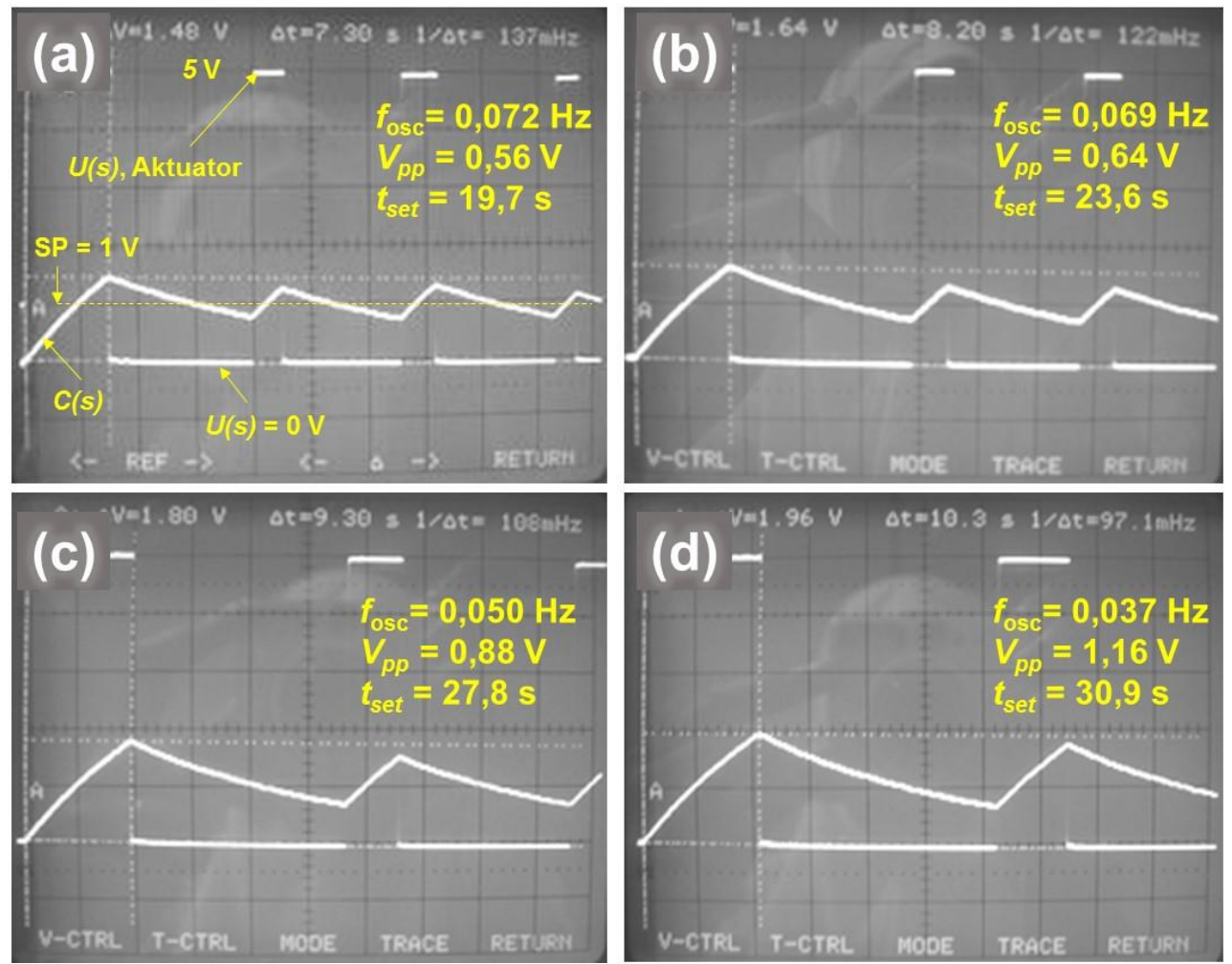

Gambar 7. Pengaruh parameter waktu-tunda histeresis terhadap frekuensi dan amplitudo osilasi respon untuk $\mathrm{G}(\mathrm{s})=1 /(22 \mathrm{~s}+1)$ dan $\mathrm{H}(\mathrm{s})=1 /(2,2 \mathrm{~s}+1)$, dengan penguatan, $M$ sebesar $5 \mathrm{~V}$ dan variasi waktu-tunda,

$T$ (a) $0,5 \mathrm{~s}$, (b) $1 \mathrm{~s}$, (c) $1,5 \mathrm{~s}$ dan (d) $2 \mathrm{~s}$

\section{Kesimpulan}

Berdasarkan pengukuran dan pembahasan diperoleh bahwa dengan melakukan analisis dinamik performansi pengontrol on-off, dapat ditentukan nilai-nilai parameter $T$ dan $M$ pengontrol on-off agar memperoleh respon variabel kontrol yang diinginkan yang sesuai dengan kriteria pengontrolan untuk sistem $G(s)$ dan $H(s)$ tertentu yang diberikan. Hal ini juga ditunjukkan dengan hasil simulasi Matlab untuk sistem yang sama.

\section{Ucapan terima kasih}

Terima kasih kepada Direktorat Riset, Pengabdian kepada Masyarakat dan Inovasi, dan Fakultas MIPA, Universitas Padjadjaran atas penyediaan fasilitas alat ukur di Laboratorium Elektronika dan Laboratorium Komputer.

\section{Daftar Pustaka}

[1] Katsuhiko Ogata. Modern Control Engineering. Fifth Edition. New Jersey: Pearson Education, Inc., Prentice Hall. 2010: 1-10.

[2] Tomáš Uriča, Anna Simonová. Procedia Engineering 2017; 192: 905 - 910.

[3] Darmawan Hidayat, Eppstian Syah As'ari, Nendi Suhendi Syafei. EKSAKTA: Berkala Ilmiah Bidang MIPA 2017; 18(2): 178 - 185.

[4] E. Mirzaee-Ghaleh, M. Omid, A. Keyhani, M.J. Dalvand. Computers and Electronics in Agriculture 2015; 110: 187-195.

[5] Restrepo, A., González, A., Orduz, S. 2002. Chem. Eng. J., 89: 101-107.

[6] Darmawan Hidayat, W Widiyastuti, Takashi Ogi, Kikuo Okuyama. Aerosol Science and Technology 2010; 44(8): 692-705.

[7] Giulia Ulpiani, Matteo Borgognoni, Alessandra Romagnoli, Costanzo Di Perna. Energy and Buildings 2016; 116: 1-17. 
[8] Yemao Li, Jianjun Xia. Energy Procedia 2017; 116: 452 - 459.

[9] U. Hoffmann, U. Muller, B. Schurmann and H. Rake. IFAC Proceedings 1984; 17(2): 27772782.

[10] Sina Faizollahzadeh Ardabili, Asghar Mahmoudi, Tarahom Mesri Gundoshmian, Ali Roshanianfard. Measurement 2016; 90: 127-134.

[11] Whyman, D. Comput. Edu. 1988; 12(4): 493-500.

[12] Chang-Soon Kang, Chang-Ho Hyun, Mignon Park. Applied Energy 2015; 155: 270-283.

[13] J. Dostal, L. Ferkl. IFAC Proceedings 2014; 47(3): 4423-4428.

[14] Abdul Afram, Farrokh Janabi-Sharifi. Journal of Process Control 2016; 47: 161-174. 